\title{
Comparing some blood parameters of ski racers and long- distance athletes
}

\author{
Metin BAYRAM ${ }^{1}$, Gokhan BAYRAKTAR ${ }^{1}$, Harun AKYOL ${ }^{1}$, Banu CAN ${ }^{2}$ \\ ${ }^{1}$ School of Physical Education and Sport, A $\breve{g} r$ İbrahim Çecen University, A $\breve{g r l}$, Turkey. \\ ${ }^{2}$ Faculty of Sport Sciences, Selçuk University, Konya, Turkey. \\ Address correspondence to M. Bayram, e-mail: metinbayram04@hotmail.com
}

\begin{abstract}
The aim of this study is to make a comparison of some blood parameters of the elite level strength athletes in two different branches. The resent study included 30 female and 30 male subjects at the ages of 18-22. Twenty of them (10 female and 10 male) were elite long distance athletes and other 20 of them (10 female and 10 male) were elite ski-racer athletes. Twenty subjects were sedentary ( 10 female and 10 male). They did not have any sport experience. Blood samples were taken at the resting state after briefing the test subjects during the period of competition. $5 \mathrm{ml}$ blood samples taken from the forearm were collected in EDTA tubes at 10.00-11.00am and biochemical analyzes were performed at the Central Laboratory of Biochemistry in Agri State Hospital. In the analysis, Shapiro Wilk, Mann-Whitney and Kruskal-Wallis tests were used. According to the biochemical results of male athletes, while there is no significant correlation between the values of Glucose, ALT, Triglycerides, Cholesterol, HDL, LDL, FE Binding Capacity, Creatinine Kinase and MG, a significant correlation were found in the BUN value between skiers with athlete and control groups, in the Albumin value between athlete and control groups, in the NA value between athlete and control groups, in the AST value between athlete and skiers groups, in uric acid value among all groups, in CA value among all groups, in creatinine value among all groups. According to the biochemistry results of female athletes located in skiers, athlete and control groups, a statistically significant difference was observed between control and skier groups in terms of CA value $(\mathrm{p}=0.04)$. There are meaningful differences between the control and athlete groups and between control and skier groups in terms of Creatinine Kinase value $(p=0.00)$. There was not any significant correlation between the groups compared to the other parameters. When athletes in the control and experimental groups were compared among themselves, significant differences have been found in some blood parameters but it has not been observed any differences in some other parameters.
\end{abstract}

Keywords: Athletics, ski, ski run.

\section{INTRODUCTION}

Endurance Training is physical and psychological performance carried out to increase technical and tactical skills through physical and motivational capability. That is, endurance is a method of systematic preparation for making athletes reach the highest sportive activity. Physical activity is an important function for living organisms. It may affect hematologic and biochemical parameters as well as several systems. Hematologic and biochemical levels may also play an important role in human adaptation to training, in adaptation of cardiovascular activity and in arrangement of physical impulse such as physical and physiologic balance in addition to several other factors (6). Exercises provide athlete body with resistance, increase effort and strength and put off exhaustion. Physiologic and biochemical reserves directly affect current strength and endurance. Recognition of physical and biochemical reserves and observation of their effect on training or practices are vital. Several research show that biochemical blood parameters significantly affect performance. Hematologic and biochemical parameters (Bun, Albumin, Na, Ast, Alt, Uric acid, $\mathrm{Ca}$, Creatinin) may vary depending on type, intensity and duration of exercise (23). Hematologic and biochemical values measured during and subsequent to intense exercise may vary because of variations such as exercise type, sex, age, ambient conditions and nutrition. Athletes reveal hematologic variations in long-lasting exercises (10). Adult females are exposed to iron loss in high amounts in menstrual periods through less rate of hemoglobin. Various blood parameters may vary depending on iron loss (37). Bayram et al. found that there is a significant difference in the values of 
cortisol and folate in female athletes and female skiers when the values of sportsmen and sedanters are compared in the study they performed and this difference may be based on more intense training of athletes than skiers. Cortisol, Ferritin, Free T4, Folate, and vit B12 values were found statistically higher in male group. This difference can be attributed to the higher loading of men's training load, muscle structure, male hormone and vital capacities, and supports my work (9). Intense exercise is known to incur several levels of damage in muscles. Particularly, research on detection of damage in skeletal muscle are currently in place $(26,27)$. Exercises increase the workload on heart, and the type of exercise specifies the size of this workload. ALT alanine aminotransferase and AST aspartate aminotransferase are sensitive indicators for damage of liver and muscle cells, so the effects of chronic exercise on ALT and AST are under research (29). The effects of chronic exercises on biochemical parameters may vary depending on features of individuals, their physical conditions, duration and intensity of exercise and various lipid values. According to the study, female and male athletes in both athlete groups were subject to observation of some hematologic and biochemical parameters in a period when they prepared for selection of national team, and how intense exercises affect some hematologic and biochemical levels of female ski racers and female athletes and male ski racers and male athletes is aimed to be detected. Similar to our study results, a study of elite kickboxing athletes and boxers reported a statistically significant increase in serum AST and ALT levels after intensive exercise $(8,25)$.

Short-time and long-time exercises cause significant changes in structure and functionality of a body. Exercise is accepted to be necessary for optimally sustaining structure and functionality of muscle, bone, articulation, cardiovascular system for any interval of age. The ones making regular endurance sport activities are rarely subject to diseases such as coronary artery diseases, hypertension and diabetes, such children are more apt to grow healthily, and elder people live more comfortably and self-sufficiently $(3,5,15,19)$. Exercises provide body with resistance, increase strength and putting of exhaustion. Physiologic and biochemical reserves directly affect current strength and endurance. Recognition of physical and biochemical reserves and observation of their effect on training or practices are vital. Many research show that blood biochemical parameters significantly affect performance (AST, ALT, HDL, Glucose, Triglyceride, hematocrit, BUN, Albumin, na, ALT, AST, Uric acid $(4,13,31,32)$. The resent study aimed to compare some blood parameters in elite long distance athletes, elite ski-racer athletes and sedentary.

\section{MATERIALS \& METHODS}

\section{Population of Study}

The resent study included 30 female and 30 male subjects at the ages of 18-22. Twenty of them (10 female and 10 male) were elite long distance athletes and other 20 of them (10 female and 10 male) were elite ski-racer athletes. They were athletes of Ağrı Youth Services and Sports Provincial Directorate. Twenty subjects were sedentary (10 female and 10 male). They did not have any sport experience.

\section{Blood Tests}

Blood samples are taken in a period of competition of athletes upon acknowledgment. Test subjects did not intake food or liquid as of 22:00 on the day before taking measurements. The blood samples are collected in $5 \mathrm{ml}$ EDTA tubes from forearm in a relaxed position at 10:00-11:00 in morning.

\section{Biochemical Tests}

Biochemical analyses are made in Agri State Hospital Biochemical Center laboratory, and the values of pre-specified parameters (Blood Urea Nitrogen (BUN), Albumin, Sodium (Na), Glucose, Alanine Aminotransferase (ALT), Aspartate Transaminase (AST), Uric Acid, Triglyceride, Cholesterol, (HDL), Cholesterol (LDL), Fe B. Cap iron, Calcium (Ca), Chlorine $(\mathrm{Cl})$, Magnesium $(\mathrm{Mg})$ and Creatinine, Creatinine Kinase $(\mathrm{CK})$ ) are detected in the biochemical laboratories.

\section{Statistical Method}

The statistical analyses for the study were conducted using the SPSS 19.0 statistic packet program. The descriptive statistics for permanent variables in the study were the mean and standard deviation (SD). A Shapiro Wilk test was used for normality analyses. Mann Whitney U test were used for 2-group comparison of variables without normal distribution, Kruskal Wallis test were used for 3- or more-group comparisons, and Bonferonni-corrected Mann Whitney $U$ test were used for 2-sub- 
comparisons for significant variables. Yates $\mathrm{Ki}$ square test were used for group comparisons of categorical variables. Comparisons under value $p=0.05$ were accepted statistically significant for all statistical analyses in the study.

\section{RESULTS}

Table 1 shows that, according to the biochemical test results of the athletes in male ski racer, athlete and control group, there is no significant relationship between Glucose, ALT, Triglyceride, Cholesterol, HDL, LDL, FE Bon. Capacity, Creatinine Kinase and MG values, whereas BUN values shows significant correlation between ski racer and athlete group and control groups, Albumin shows the same between control group and athlete group, NA values between the control group and the athlete group, AST values between athlete group and ski racer group, Uric Acid values between all groups, CA values between all groups and Creatinine values between all groups.

Table 2 shows that, according to biochemical results of the athletes in the female ski racer group and athlete group, there is a significant statistical relationship in terms of "Ca" between the groups "control" and "ski racer" $(p=0.04)$. There is a significant statistical correlation between the groups "control" and "athlete" and between the groups "control" and "ski racer" in terms of "Creatinine Kinase" $(p=0.00)$. There is a significant correlation between the groups observing other parameters.

Table 1. Kruskal Wallis test comparison for biochemical parameters of male test subjects (Mean \pm SD).

\begin{tabular}{|c|c|c|c|c|c|}
\hline Parameters & Control Group & Long-Distance Athlete & Ski Racer & Ki-square & $\mathrm{p}$ \\
\hline Blood Urea Nitrogen (BUN) & $13.9 \pm 3.7$ & $16.3 \pm 2.0$ & $19.0 \pm 3.0$ & 9.016 & $0.01^{*}$ \\
\hline Albumin & $5.0 \pm 0.2$ & $4.8 \pm 0.2$ & $4.8 \pm 0.2$ & 6.074 & $0.03^{*}$ \\
\hline Sodium (Na) & $141.4 \pm 0.9$ & $139.1 \pm 1.1$ & $139.4 \pm 1.8$ & 9.742 & $0.01^{*}$ \\
\hline Glucose & $86.25 \pm 13.21$ & $87.44 \pm 10.36$ & $86.78 \pm 10.56$ & 0.088 & 0.96 \\
\hline Alanine Aminotransferase (ALT) & $26.13 \pm 13.68$ & $24.00 \pm 9.21$ & $14.89 \pm 1.90$ & 5.086 & 0.08 \\
\hline Aspartate Transaminase (AST) & $31.25 \pm 15.91$ & $38.67 \pm 11.18$ & $21.44 \pm 4.56$ & 10.037 & $0.01^{*}$ \\
\hline Uric Acid & $5.70 \pm 0.78$ & $4.63 \pm 1.05$ & $5.93 \pm 1.05$ & 7.210 & $0.03^{*}$ \\
\hline Triglyceride & $69.38 \pm 26.60$ & $81.33 \pm 42.93$ & $85.89 \pm 52.09$ & 0.389 & 0.82 \\
\hline Cholesterol & $138.50 \pm 28.48$ & $144.33 \pm 14.00$ & $140.78 \pm 16.12$ & 0.168 & 0.92 \\
\hline Cholesterol (HDL) & $47.00 \pm 4.69$ & $54.00 \pm 13.37$ & $51.33 \pm 11.09$ & 0.912 & 0.63 \\
\hline Cholesterol (LDL) & $77.63 \pm 27.45$ & $74.67 \pm 11.62$ & $72.33 \pm 12.17$ & 2.186 & 0.34 \\
\hline Fe Bon. Cap. & $199.88 \pm 57.94$ & $217.44 \pm 68.99$ & $244.22 \pm 60.47$ & 2.129 & 0.35 \\
\hline Calcium (Ca) & $10.15 \pm 0.25$ & $10.14 \pm 0.28$ & $10.55 \pm 0.30$ & 7.292 & $0.03^{*}$ \\
\hline Chlorine $(\mathrm{Cl})$ & $101.29 \pm 1.95$ & $100.44 \pm 1.17$ & $100.98 \pm 1.63$ & 0.891 & 0.64 \\
\hline Magnesium (Mg) & $1.9 \pm 0.2$ & $1.8 \pm 0.1$ & $1.8 \pm 0.1$ & 5.201 & 0.07 \\
\hline Creatinine & $1.1 \pm 0.1$ & $0.8 \pm 0.1$ & $0.9 \pm 0.1$ & 16.514 & $0.00^{*}$ \\
\hline Creatinine Kinase & $378.4 \pm 275.4$ & $499.3 \pm 172.5$ & $284.4 \pm 179.8$ & 4.806 & 0.09 \\
\hline
\end{tabular}

${ }^{*} \mathrm{p}<0.05$

Table 2. Kruskal Wallis test comparison of biochemical parameters of female test subjects.

\begin{tabular}{|c|c|c|c|c|c|}
\hline Parameters & Control Group & Long-Distance Athlete & Ski Racer & Ki-square & $\mathrm{p}$ \\
\hline Blood Urea Nitrogen (BUN) & $11.1 \pm 2.9$ & $14.4 \pm 3.8$ & $13.6 \pm 2.7$ & 4.66 & 0.10 \\
\hline Albumin & $4.8 \pm 0.5$ & $4.7 \pm 0.2$ & $4.6 \pm 0.3$ & 1.70 & 0.43 \\
\hline Sodium (Na) & $139.9 \pm 2.1$ & $139.0 \pm 1.4$ & $140.1 \pm 1.7$ & 1.72 & 0.42 \\
\hline Glucose & $90.75 \pm 11.78$ & $86.89 \pm 12.04$ & $79.56 \pm 14.05$ & 2.53 & 0.28 \\
\hline Alanine aminotransferase (ALT) & $12.00 \pm 3.25$ & $19.67 \pm 9.39$ & $14.11 \pm 6.64$ & 5.27 & 0.07 \\
\hline Aspartate transaminase (AST) & $17.75 \pm 2.60$ & $23.33 \pm 6.58$ & $21.11 \pm 5.84$ & 3.71 & 0.16 \\
\hline Uric Acid & $3.75 \pm 0.46$ & $4.27 \pm 0.41$ & $4.24 \pm 0.65$ & 5.49 & 0.06 \\
\hline Triglyceride & $77.00 \pm 39.37$ & $71.78 \pm 29.62$ & $52.89 \pm 23.04$ & 1.91 & 0.39 \\
\hline Cholesterol & $158.50 \pm 31.33$ & $152.11 \pm 8.34$ & $148.67 \pm 21.59$ & 0.04 & 0.98 \\
\hline Cholesterol (HDL) & $57.3 \pm 19.4$ & $63.1 \pm 9.0$ & $60.6 \pm 17.1$ & 3.09 & 0.21 \\
\hline Cholesterol (LDL) & $81.4 \pm 13.7$ & $75.3 \pm 8.9$ & $77.4 \pm 18.0$ & 0.57 & 0.75 \\
\hline Fe Bon. Cap. & $299.1 \pm 80.3$ & $234.8 \pm 55.3$ & $251.4 \pm 48.8$ & 2.77 & 0.25 \\
\hline Calcium (Ca) & $9.7 \pm 0.4$ & $10.1 \pm 0.6$ & $10.3 \pm 0.3$ & 6.71 & 0.04 \\
\hline Chlorine $(\mathrm{Cl})$ & $102.2 \pm 2.0$ & $101.3 \pm 1.4$ & $102.3 \pm 1.0$ & 3.37 & 0.19 \\
\hline Magnesium (Mg) & $1.8 \pm 0.1$ & $1.8 \pm 0.1$ & $1.7 \pm 0.1$ & 4.62 & 0.10 \\
\hline Creatinine & $0.8 \pm 0.1$ & $0.7 \pm 0.1$ & $0.8 \pm 0.1$ & 4.79 & 0.09 \\
\hline Creatinine Kinase (CK) & $96.0 \pm 34.1$ & $175.4 \pm 69.6$ & $222.3 \pm 116.2$ & 11.33 & $0.00^{* *}$ \\
\hline
\end{tabular}




\section{DISCUSSION}

The study shows that exercise programs incur significant increases and decreases in some blood levels of female and male athletes, which implies similarities with and differences from the support in several research. It is determined that it causes insignificant decrease in blood levels of male athletes, so it is stated that intra-blood hemolysis subsequent to mechanical trauma due to intense exercise may cause decreases. It is also stated that long-time exercise may adversely affect performance due to decrease in some blood levels. (36). However, it is accepted as favorable that findings derived are within normal health limits. Particularly for the values of analyses such as Glucose, Total cholesterol, LDL-cholesterol, Triglyceride detected in the study, studies in decision limits are required. These approaches show that use of reference intervals derived within routine applications and promotion through new ideas and studies are some required processes. On the other hand, our study does not show significant difference in terms of female and male HDL cholesterol values. As a result of our study, we can report a statistically significant increase in serum total cholesterol, HDL-C and LDL$\mathrm{C}$ levels in kick boxing athletes after intensive an exercise but no significant difference in triglyceride levels.

The study shows that male and female subjects have no significant difference in terms of liver enzymes AST and ALT. The results of this study, once again, shows that reference values may change with respect to the society the clinic laboratory provides service for. These differences may arise from sex, geographical position, socio-economic level and associatively nutrition, use of cigarette and alcohol and exercise. Therefore, each clinic laboratory should use reference intervals for their own society. A clinic laboratory should make the validation of reference values used as stated in accreditation documents arranged for its service terms and standards.

Observing the blood levels of female ski racers and female athletes in the study (Table 1), a significant increase in $\mathrm{Ca}$ and Creatinine Kinase levels occur.

Low level of Creatinine in females is not considered as a significant health problem in most cases. However, it may be an indicator of threatening disease in some cases. The blood levels of test subjects after $10 \mathrm{~km}$. running shows a significant increase $(p<0.05)$. It is stated that acute submaximal exercise increases blood levels significantly compared to pre-exercise values, and this increase is stated to be related to plasma loss due to exercises. Hazar et al. (21). Again, observing the blood levels of male ski racers and male athletes (Table 2), there is a significant difference in the levels of Bun, Albumin, $\mathrm{Na}$, Ast, Uric acid, $\mathrm{Ca}$, Creatinine $(p>0.05)$. This significant difference of blood levels in males despite insignificance in this respect in females arises from lack of protein nutrition of females or high level of water before exercise or disobedience to warnings before blood tests. As their muscle metabolism is high due to intense exercise, some serum results may yield low values. Thus, it is considered that plasma loss is more rapidly tolerated or is formed in less amount $(12,38)$. This means that intense exercises also lack in overcoming health problems, which is a remarkable finding. Similarly, Lien et al. (2006) declared no significant difference, after 12 weeks, in some parameter levels of 14 male and 23 female athletes making regular exercises for 12 weeks (18). Prior to and subsequent to a 2-week exercise program applied on 9 sedentary and 9 athlete test subjects, none of the groups showed a significant difference. The reason for this difference to be insignificant is considered to be related to intensity of the exercise, and this study is similar to our study (Gunay et al. 2001). There are many studies about effects of exercise on hematologic parameters (20). It is stated that blood parameters affect type and intensity of exercises, and similarly exercise influences blood parameters. Exercise is one of the most intense stress the human body is exposed to. The study investigates how acute exercise affects some hematologic and biochemical parameters (2). A study on 7 sedentary test subjects after 4 weeks of an 8 -week exercise program, the values did not show a significant difference, but following weeks yielded significant increases. The reason for the findings to be significant in the following weeks despite insignificant values in the first 4 weeks is considered to be related to the fact that the athletes are more trained as time elapse. The current study considers that the values of all athletes does not have significant difference and there is a decrease because of intensity of exercise or altitude of the exercise place (35). The study carried out in Olympic athletes shows that blood levels of athletes in sport branches where endurance is important are higher than 
others. The current study also shows similarity to literature considering that the findings derived from the athletes participated are trained. On the other hand, (28). The acute measurements taken after 1999 Beppu-Oita Mainichi marathon from 32-year-old marathon runners yielded significant increases in total number of leucocytes and leucocyte rates.

The study detected a significant difference on some values of female athletes in acute exercise $(p>0.05)$ while some values showed significant decrease.

Some blood values of male athletes are more significant compared to female athletes $(p>0.05)$. Studies promoting the research are similar with the literature. The region of living, sex, age, nutrition habits, method used in test measurement and many related factors affect reference values.

Although the results of the study are within the limits determined for normal people, several studies show that blood parameter levels of athletes are lower than the same of other people $(14,16,24,39)$.

In conclusion, observing the blood parameters of long-distance runners and ski racers, the male athletes in the ski racers, athlete and control groups show no significant correlation between Glucose, ALT, Triglyceride, Cholesterol, HDL, LDL, FE Bon. Capacity, Creatinine Kinase and MG values according to biochemical results while ski racer and athlete and control groups show correlation in terms of BUN values, ski racer and athlete groups in terms of Albumin values, control and athlete groups in terms of NA values, athlete and ski racer groups in terms of AST values, all groups in terms of Uric Acid values, all groups in terms of CA values and all groups in terms of Creatinine values showed significant correlation. According to biochemical results of female ski racer, athlete and control groups, there is a statistical significant difference between the groups "control" and "ski racer" in terms of "Ca". There is a statistical significant difference between the groups "control" and "athlete" as well as between the groups "control" and "ski racer". There is no significant correlation between the groups in terms of other parameters.

\section{ACKNOWLEDGEMENT}

This study was supported by the Scientific Researches Coordinatorship (BAP) of Agri Ibrahim Cecen University.

\section{REFERENCES}

1. Abulencia A, Adelman J, Affolder T, Akimoto T, Albrow MG, Ambrose D, Annovi A. et al. Measurement of the $t^{t}$ production cross section in $\mathrm{p} \mathrm{p}^{-}$collisions at $\mathrm{s}=1.96 \mathrm{TeV}$ in the all hadronic decay mode. Physical Review D, 2006; 74(7): 072005.

2. Achten J, Jeukendrup AE. Heart rate monitoring. Sports medicine, 2003; 33(7): 517-538.

3. Adams JED, Abendschein DR, Jaffe AS. Biochemical markers of myocardial injury. Is MB creatine kinase the choice for the 1990s. Circulation, 1993; 88(2): 750-763.

4. Aggön E. The effects of progressive relaxation exercises applied to young ski jumpers on oxidative DNA damage. Studies on Ethno-Medicine, 2017; 11(1): 28-34.

5. Akgün N. Egzersiz Fizyolojisi. İzmir, Ege Üniversitesi Yayınları, 1986.

6. Arslan C, Bingölbalı A, Kutlu M, Baltacı A. The effects of volleyball, track and field sports on girls' hematological and biochemical parameters. Journal of Physical Education and Sport Sciences, 1997; 2(3): 28-34.

7. Baltacı AK, Moğulkoç R, Üstündağ B, Koç S, Özmerdivenli R. A study on some hematological parameters and the levels of plasma proteins and serum zinc, calcium and phosphorus in young female athletes. Journal of Physical Education and Sport Sciences, 1998; 3: 21-30.

8. Baygutalp NK, Ozturk N, Bakan E, Kurt N, Mehmet AG, Dorman E, Kiyici F, Kaynar O, Yazici AG. Acute effects of training on some biochemical analytes in professional boxers sub-title: Biochemical analytes in boxers. International Journal, 2016; 4(1): 39-52.

9. Bayram M, Demirel N, Tuğrulhan ŞC. Dayaniklilik sporu yapan elit düzeydeki bayan ve erkek atletler ile bayan ve erkek kayakli koşucularin bazi kan parametrelerindeki değişimin incelenmesi. Atatürk Üniversitesi Beden Eğitimi ve Spor Bilimleri Derg, 2016; 18(1): 27-36

10. Beydağı H, Çoksevim B, Temoçin S, Akar S. Akut submaksimal egzersizin spor yapan ve yapmayan kişilerde koagülasyona etkisi. Spor Hek Derg, 1992; 27: 113-119.

11. Beydağı H, Çoksevim B, Temoçin S, Akar S. Akut submaksimal egzersizin spor yapan ve yapmayan kişilerde lökositlere etkisi. Spor Hek Derg, 1993; 28: 52-62.

12. Bezci Ş, Kaya Y. The analyze of hematological parameters of elite women taekwondoers before and after training. Pamukkale J Sport Sci, 2010; 1(2): 1-16.

13. Civan F. (2010). Effective correlation of apparent gas permeability in tight porous media. Transport in porous media, 2010; 82(2): 375-384.

14. Çolakoğlu F, Şenel Ö. Sekiz haftalık aerobik egzersiz programının sedanter orta yaşlı bayanların vücut kompozisyonu ve kan lipidleri üzerindeki etkileri. Ankara Üniversitesi Beden Eğitimi ve Spor Bilimleri Dergisi, 2003; 1(1): 56-61.

15. Duarte JA, Appell HJ, Carvalho F, Bastos ML, Soares JM. Endothelium-derived oxidative stress may contribute to exercise-induced muscle damage. International Journal of Sports Medicine, 1993; 14(8): 440-443. 
16. Duff K, Eckman C, Zehr C, Yu X, Prada CM, Perez-Tur J, Morgan D. Increased amyloid- $\beta 42$ (43) in brains of mice expressing mutant presenilin 1 . Nature, 1996; 383(6602), 710 713.

17. Goodman R, Wallach NR. Representations and invariants of the classical groups (Vol. 68). Cambridge University Press, 2000.

18. Güray Ü, Erbay AR, Güray Y, Yilmaz MB, Boyacı AA, Sasmaz $H$, Kütük E. Levels of soluble adhesion molecules in various clinical presentations of coronary atherosclerosis. International Journal of Cardiology, 2004; 96(2): 235-240.

19. Gutteridge JM. Lipid peroxidation and antioxidants as biomarkers of tissue damage. Clinical chemistry, 1995; 41(12): 1819-1828.

20. Guyton AC, Hall JE. Overview of the circulation: medical physics of pressure, flow, and resistance. Textbook of medical physiology, 1996.

21. Hazar S, Gökdemir K. Aerobik ve anaerobik egzersizlerin hematolojik parametrelere akut etkisi. In 10th International Sports Science Congress. October, 23-25, 2008, Bolu, Turkey.

22. Jeukendrup AE. Modulation of carbohydrate and fat utilization by diet, exercise and environment. Biochemical Society Transactions, 2003; 31(6): 1270-1273.

23. Kara E, Özal M, Yavuz HU. Comparison of the blood parameters and respiratory functions of elite wrestlers and basketball players. Selçuk University Journal of Physical Education and Sport Science, 2010; 12(1): 36-41.

24. Karacan S, Çolakoğlu FF. The effects of aerobic exercise on the body composition and blood lipids in middle aged and young women. Spormetre, 2003; 2: 83-88.

25. Kaynar Ö, Öztürk N, Baygutalp NK, Bakan E, Kıyıcı F. The effects of short-term intensive exercise on levels of liver enzymes and serum lipids in kick boxing athletes. Dicle Medical Journal, 2016; 43(1): 130-134.

26. Newham DJ, Jones DA, Edwards RHT. Plasma creatine kinase changes after eccentric and concentric contractions. Muscle \& nerve, 1986; 9(1): 59-63.

27. Nosaka K, Clarkson PM. Influence of previous concentric exercise on eccentric exercise-induced muscle damage. Journal of Sports Sciences, 1997; 15(5): 477-483.

28. Patlar S, Keskin E. The effects of glycerol supplement on various hematologic parameters in sedentaries and the athletes who exercise regularly. Exercise, 2007; 1: 23-35.

29. Perlmutter DH, Dinarello CA, Punsal PI, Colten HR Cachectin/tumor necrosis factor regulates hepatic acute-phase gene expression. Journal of Clinical Investigation, 1986; 78(5): 1349.

30. Schneider CM, Dennehy CA, Rodearmel SJ, Hayward JR. Effects of physical activity on creatine phosphokinase and the isoenzyme creatine kinase-MB. Annals of Emergency Medicine, 1995; 25(4): 520-524.

31. Schwane JA, Buckley RT, Dipaolo DP, Atkinson MA, Shepherd JR. Plasma creatine kinase responses of 18-to 30-yrold African-American men to eccentric exercise. Medicine and science in sports and exercise, 2000; 32(2): 370-378.

32. Schwane JA, Johnson SR, Vandenakker CB, Armstrong RB. Delayed-onset muscular soreness and plasma CPK and LDH activities after downhill running. Medicine and Science in Sports and Exercise, 1982; 15(1): 51-56.

33. Schwane JA, Buckley RT, Dipaolo DP, Atkinson MA, Shepherd JR. Plasma creatine kinase responses of 18-to 30-yrold African-American men to eccentric exercise. Medicine and Science in Sports and Exercise, 2000; 32(2): 370-378.

34. Smith JC, Price BMJ, Green JBA, Weigel D, Herrmann BG Expression of a Xenopus homolog of Brachyury (T) is an immediate-early response to mesoderm induction. Cell, 1991; 67(1): 79-87.

35. Spodaryk K. Haematological and iron-related parameters of male endurance and strength trained athletes. European journal of Applied Physiology and Occupational Physiology, 1993; 67(1): 66-70

36. Taşkıran Y, Varol RO. Defansif savunma sonrası hızlı hücuma çıkan kanat ve iç savunma oyuncularının $30 \mathrm{~m}$. sprint değerlerinin karşılaştııılması. Performans Dergisi, 1995; 1(1): 25-29

37. Tran ZV, Weltman A. Differential effects of exercise on serum lipid and lipoprotein levels seen with changes in body weight: a meta-analysis. Jama, 1985; 254(7): 919-924.

38. Vita JA, Frei B, Holbrook M, Gokce N, Leaf C, Keaney JrJF. L2-Oxothiazolidine-4-carboxylic acid reverses endothelial dysfunction in patients with coronary artery disease. Journal of Clinical Investigation, 1998; 101(6): 1408.

39. Wallach S, Cohen S, Reid DM, Hughes RA, Hosking DJ, Laan $\mathrm{RF}$, Barton I. Effects of risedronate treatment on bone density and vertebral fracture in patients on corticosteroid therapy. Calcified Tissue International, 2000; 67(4): 27.

40. Wu SM, Fujiwara Y, Cibulsky SM, Clapham DE, Lien CL, Schultheiss TM, Orkin SH. Developmental origin of a bipotential myocardial and smooth muscle cell precursor in the mammalian heart. Cell, 2006; 127(6): 1137-1150. 